\title{
Cognitive Instruments Of Public Management Accountability For Development Of National Innovation System
}

\author{
Nataliia Gavkalova, Svitlana Labunska, Andriy Pylypenko, Olena Prokopishyna \\ Simon Kuznets Kharkiv National University of Economics \\ 9a, Nauku av., Kharkiv, Ukraine \\ cross $^{\text {ref }}$ http://dx.doi.org/10.5755/j01.ppaa.18.3.24727
}

\begin{abstract}
The main aim of the research was to develop cognitive instruments that allow justification of decisions in national innovation policy. In the theoretical part of research fundamentals of national innovation policies of EU-members and Ukraine were compared to reveal factors that can accelerate innovation development. In the empirical part of research the analysis of innovation capability of Ukrainian enterprises was conducted based on financial, statistic and management reports and it confirmed that companies systematically conducted innovation activities, reached higher levels of innovation potential, innovative business opportunities and margin of economic security and, consequently, have more innovative capacities for innovation of all types.

The formation of cognitive analytical base allowed the application of scenario modelling at the level of public management of innovation activity. Cognitive modelling approach was justified firstly by increased volatility in economic conditions of modern realities of crisis in the national economy, and secondly high-cost and risky innovations, fast diffusion of information resources during the introduction of innovation processes, and thirdly, the presence of the mutual influence of objects of national innovation system.
\end{abstract}

Keywords: cognitive analysis, innovations, state budget, innovative capability, national innovation policy

Raktažodžiai: pažintinè analizè, naujovès, valstybès biudžetas, naujoviški pajègumai, nacionaline inovaciju politika

\section{Introduction}

The fundamental changes in the system of public administration and the expansion of socially responsible models in economic activity determine the feasibility of considering cognitive approaches as one of the most promising directions of reforming modern management systems. However, the uncertainty of understanding the cognition, the complexity of the recommended approaches to the creation and use of cognitive systems, insufficient study of the positive and negative effects lead to limited use of cognitive approaches in the practice of administration of complex socio-economic systems. The research aims to develop cognitive tools for solving the problems of public administration in enhancing the national innovation system. The objectives of the paper are:

1. to discuss the essence of cognitive methods for management of complex social and economic systems, as well as peculiarities of cognitive application tools for public administration of innovation business activity;

2. to apply cognitive methods for evaluation of Ukraine's national innovation system and analysis of results and frequency of innovation project implementation by national companies;

3. to justify the strategic aim of the national innovation policy and major government programs that may accelerate the development of national innovation system.

In order to achieve the aim of the paper, the following methods were used in the research process: theoretical generalization - to clarify the understanding of cognitive methods and their 
specific application for public management; statistical analysis - to study, group and compare empirical data and to investigate trends in innovation activity; analysis and synthesis, systematic approach - to determine the priorities of the national innovation policy and key-factors for stimulation efficient innovation activity of Ukrainian companies.

\section{Cognitive instruments application in the sphere of public management}

The role of cognitive methods in the organisation of management cannot be overestimated because they enable the information perception of the environment (Van Rossem, Heusinkveld, Buelens, 2015). In general understanding, cognition includes the possession and mental processing of knowledge (Uotila, 2015). Cognitive methods can provide a social character of management, where all parameters of the control system operate in an organised and effective manner. The effectiveness of such systems is determined by the wealth of thinking, the development of information structure and interacting elements. Procedures of cognition are disclosed in its definition as a mental processing that uses, changes, enacts, recalls, stores, sense, and transforms knowledge in a dynamic, recursive manner (Brymer, Hitt \& Schijven, 2012).

One of the fields for practical use of cognitive methods is the creation of scenarios set for modelling the problem situation trends based on the selected control factors, different plans and forecasts for development (Martin-Alcazar, Romero-Fernandez \& Sanchez-Gardey, 2012).

Cognitive analysis and modelling are relatively new elements in the structure of the public administration system. But the transformation of public consciousness, as an unavoidable stage in construction of a market economy in Ukraine requires new methods and models in state regulation (Gavkalova \& Kolupaieva, 2018). The technology of cognitive modelling allows: to study problems with fuzzy factors and interconnections in society; to take into account rapid changes in the international environment, to use objective trends for ensuring the country's socio-economic development.

Benefits of integrating cognitive theory to public management include improving the quality of value advice provided to decision-makers in terms of both breadth of content and consistency with underlying theoretical fundamentals (Lockwood, 1999). However, cognitive models are influenced by exogenous information such as the personal predisposition of decision-makers (Porac, Thomas, \& Baden Fuller, 1989). Cognitive models are useful in many decision-making situations (Carrington, Combe \& Mumford, 2018) because they are developed based on experiential knowledge and learning.

Cognitive tools are becoming increasingly popular in the management of various economic systems (Madhavaram \& Badrinarayanan, 2011). In particular, the calculation of the Global Innovation Index, which is widely used for international comparisons agrees with the cognitive approach.

\section{International comparison of Ukraine's national innovation system}

During the assessment of Global Innovation Index International experts [2] conclude, that in 2018 Ukraine performed on innovations even better, than its current level of economic and social development would predict and during 5 previous years included Ukraine to the group of innovation achievers, which unite 3 economies in the Eastern region of Europe (Moldova, Ukraine and Malta) followed by 8 economies from the Sub-Saharan Africa region (Kenya, Rwanda, Senegal, Uganda, Mozambique, Malawi, Burundi and Tanzania), in 2018 Ukraine was ranked as the best achiever in its group.

Calculations based on Dutta, Lanvin, Wunsch-Vincent (2019) approach showed that Ukraine's score in Global Innovation Index (GII), as well as its components, outstrip average score for lower-middle countries (in group of which Ukraine is included according to World Bank Income Group Classification) and average score for upper-middle countries (figure 1). In 2018 Ukraine reached leadership in its income group by innovation output sub-index, innovation efficiency ratio and GII in total. 


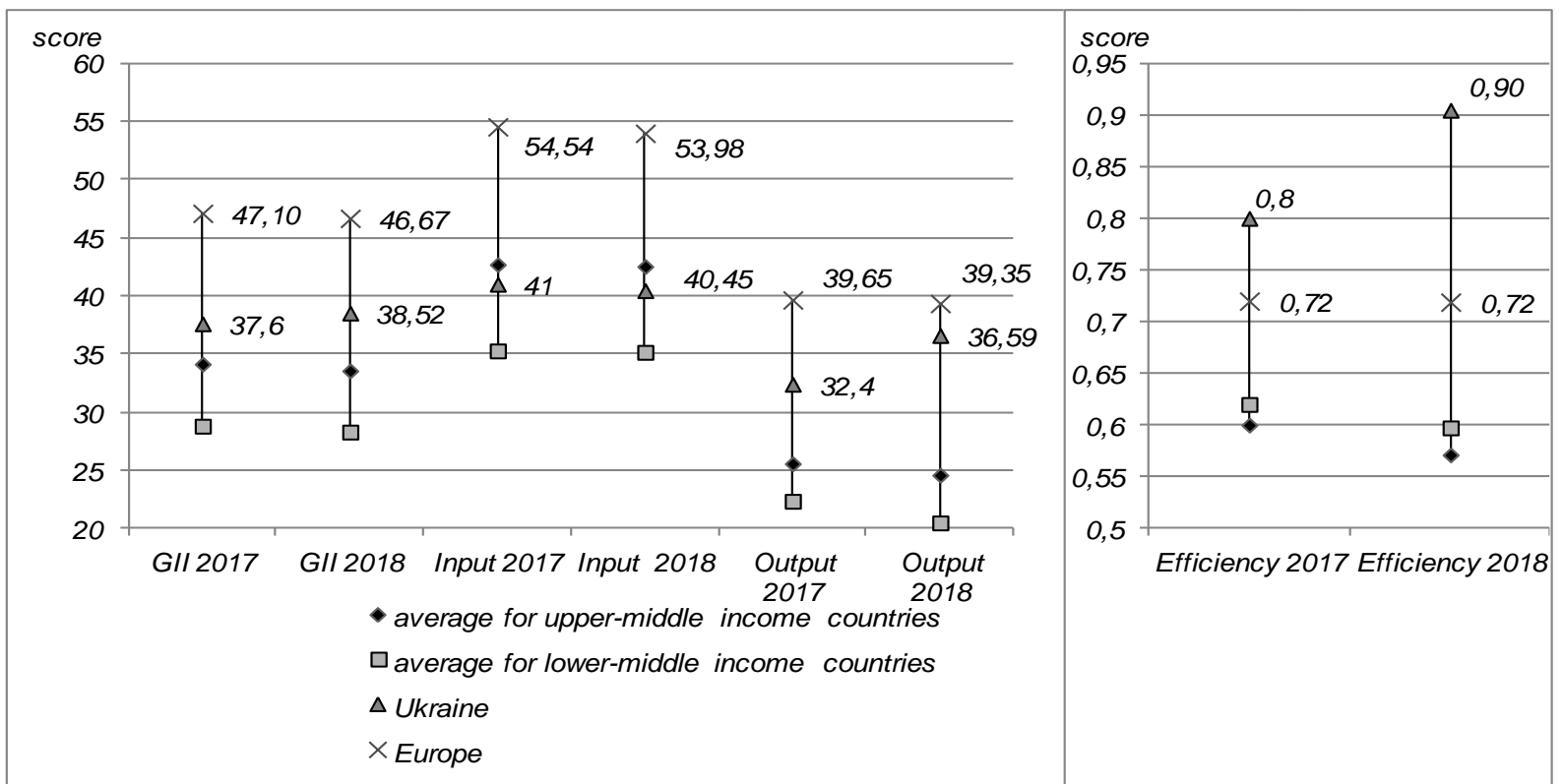

Fig. 1. Comparison of Ukraine's GII score with average lower-middle- and upper-middle-income economies.

Note. Built on data (Ukraine Statistic Innovation Outlook, 2019; Dutta, Lanvin \& Wunsch-Vincent, 2019)

But being a part of the European region, Ukraine's innovation position is not satisfactory, especially for institutions, infrastructure and market sophistication pillars. These pillars appeal to problems of public trust in the Ukrainian government and invoke studies for accountable publicprivate partnership in the sphere of innovations. Managing accountability in public-private partnerships involves balancing myriad public demands (Forrer, Kee, Newcomer \& Boyer, 2010), including cost-effectiveness, risk, innovation, stakeholder participation and security. But the experience of European countries argue for private financing of innovations for upholding the public interest.

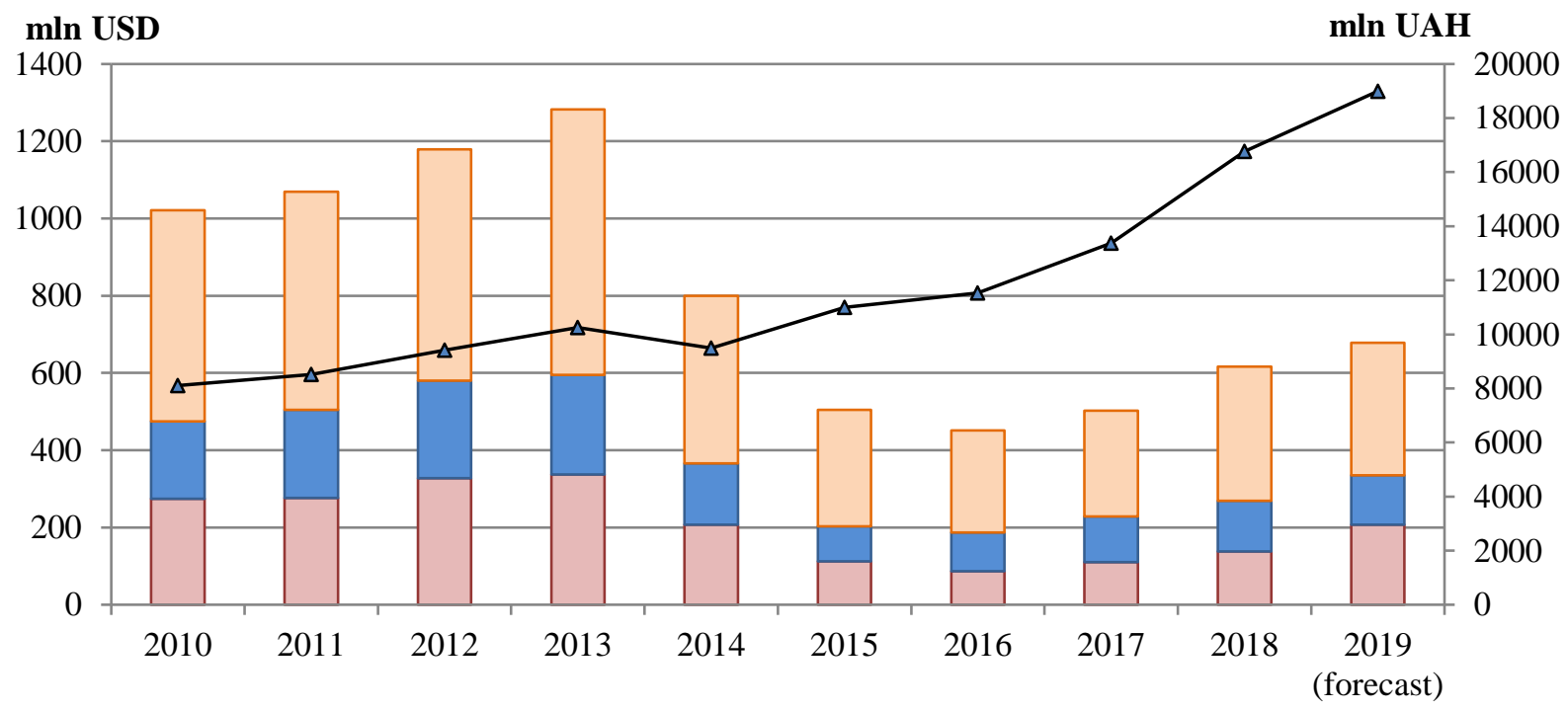

$\square$ scientific and technical (experimental) developments, USD

$\square$ applied scientific research, USD

$\square$ fundamental scientific research, USD

$\neg$ total, UAH

Fig. 2. Dynamics of research and development spending in Ukraine.

Note. Built on data (Ukraine Statistic Innovation Outlook, 2019) 
As figure 2 shows total spending on research and development in Ukraine has tendencies to increase, so in 2018 total expenditures with grow of $22.6 \%$ exceeded USD 600 million, but due to high impact of currency exchange rate fluctuations it has not reached even the half of 2013 year amount, so expenditures of 2018 were still insufficient to enable sustainable development of the national economy.

Due to limited budget revenues, government was able to finance only $37 \%$ of total R\&D expenditures (Fig. 3), but comparison with other countries of Central and Eastern Europe proves that the key factor is effectiveness and accountability of public management practice, as well as efficiency of public-business relations in the sphere of innovations.

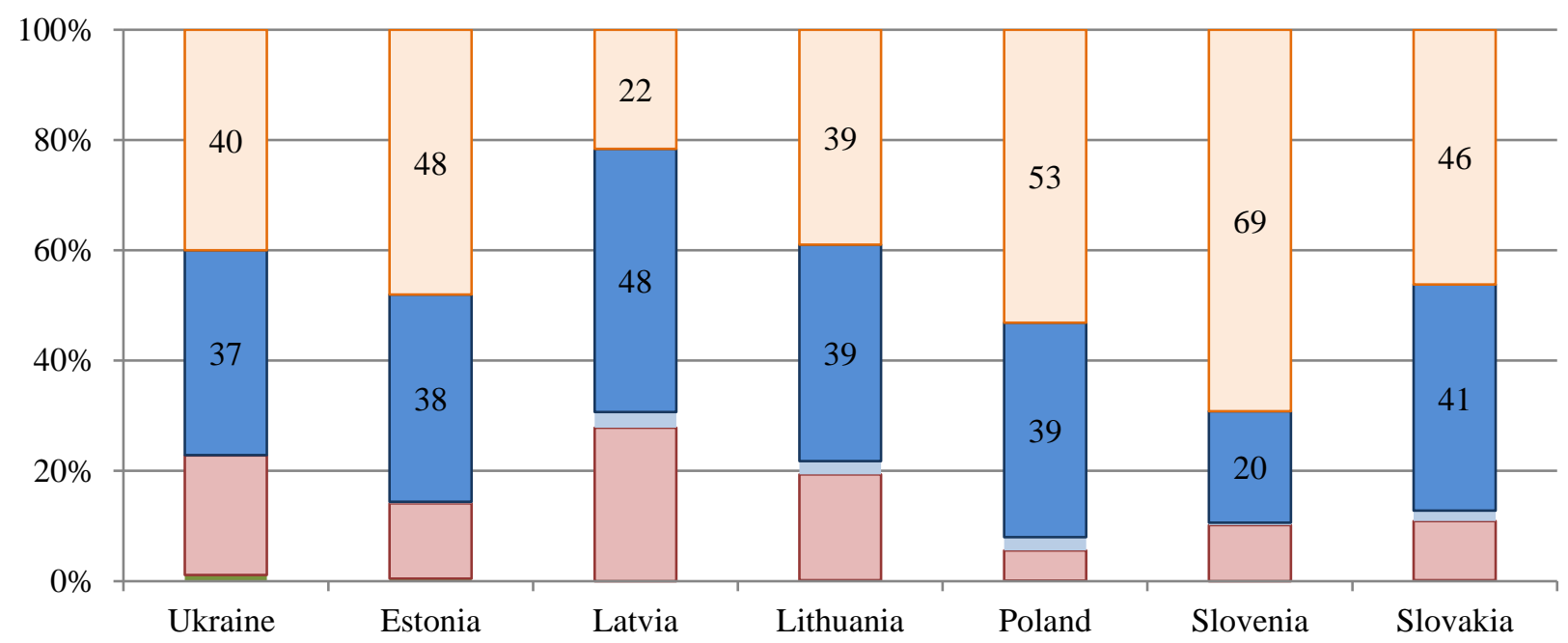

$\square$ miscellaneous $\square$ abroad $\quad \square$ higher education sector $\quad \square$ government sector $\square$ business enterprise sector

Fig. 3. R\&D expenditure by source of funds

Note. Built on data of 2018 year for Ukraine and 2016 for other countries (Ukraine Statistic Innovation Outlook, 2019 and Eurostat database, 2019)

Since 1991, the provision of budget financing of scientific and scientific and technical activities in the amount of at least $1.7 \%$ GDP as stipulated in the Law of Ukraine "On Scientific and Scientific-Technical Activity" has not been fulfilled. A typical annual amount of expenditures on science was $0.3-0.5 \%$ of GDP, and as a result, science could play a socio-cultural function in society only. Previously scholars measured that the commercial purpose of science begins with funding greater than $0.9 \%$ of GDP. The application of cognitive models allowed to justify the threshold values (Khodakivsky, Yakobchuk \& Litvinchuk, 2019) of the national innovation system parameters that ensure economic safety (table 1).

Table 1. The national safety of Ukraine in the innovation sphere.

\begin{tabular}{|c|c|c|c|c|c|c|c|}
\hline \multirow[t]{2}{*}{ Indicators, unit of measurement } & \multirow{2}{*}{$\begin{array}{c}\text { Threshold } \\
\text { value (not less } \\
\text { than) }\end{array}$} & \multicolumn{6}{|c|}{ Actual values } \\
\hline & & 2013 & 2014 & 2015 & 2016 & 2017 & 2018 \\
\hline $\begin{array}{l}\text { Share of the state budget expenditures on } \\
\text { science in GDP, } \%\end{array}$ & 1.7 & 0.31 & 0.26 & 0.26 & 0.16 & 0.16 & 0.17 \\
\hline $\begin{array}{c}\text { Share of scientific and technical workers in } \\
\text { the total number of employees, } \%\end{array}$ & 9 & 0.49 & 0.50 & 0.50 & 0.60 & 0.58 & 0.54 \\
\hline $\begin{array}{c}\text { Share of enterprises introducing } \\
\text { innovations in their total number, } \%\end{array}$ & 50 & 13.6 & 12.1 & 15.2 & 16.6 & 14.3 & $\mathrm{n} / \mathrm{a}$ \\
\hline
\end{tabular}




\begin{tabular}{|c|c|c|c|c|c|c|c|}
\hline Indicators, unit of measurement & \begin{tabular}{c} 
Threshold \\
value (not less \\
\cline { 5 - 9 }
\end{tabular} & 2013 & 2014 & 2015 & 2016 & 2017 & 2018 \\
\hline $\begin{array}{c}\text { than) } \\
\text { The share of implemented innovative } \\
\text { products in total, \% }\end{array}$ & 5 & 3.3 & 2.5 & 1.4 & $\mathrm{n} / \mathrm{a}$ & 0.7 & $\mathrm{n} / \mathrm{a}$ \\
\hline
\end{tabular}

Note. Built on data (Ukraine Statistic Innovation Outlook, 2019)

In 2018 in Ukraine, the share of the scientific and technical workers in the total number of employees was $0.54 \%$, including researchers - $0.35 \%$. According to Eurostat, in 2016 much higher shares were observed in Denmark (3.18 \% and 2.2\%), Finland (3.04 \% and $2.26 \%$ ), Great Britain $(2.29 \%$ and $1.68 \%)$, and the Netherlands $(2.28 \%$ and $1.39 \%)$.

Share of the state budget expenditures on science in GDP in Ukraine is less than the threshold value ten times. In 2018 the share of total expenditures on R\&D in GDP was $0.47 \%$, including the state budget funding of $0.17 \%$. According to the data of 2017, the share of expenditures on R\&D in the GDP of the EU-28 countries averaged $2.06 \%$. Shares of R\&D expenditures in Sweden (3.4\%), Austria (3.16\%), Denmark (3.05\%), Germany (3.02\%), Finland (2.76\%), Belgium (2.58\%) and France $(2.19 \%)$ exceed the average level. Share in Romania, Latvia, Malta, Cyprus and Bulgaria varied from $0.5 \%$ to $0.75 \%$ and were less than average level.

In general, a comparison of the distinguished threshold value with the actual values, indicates that the national innovation system of Ukraine is in a risk zone, and therefore requires the implementation of special state programs of innovation development based on principles of publicprivate partnership to ensure the accountability of public management.

\section{Justification of priorities in government maintenance of innovation activity}

The relationship between economic security and innovation activity is also maintained at the level of corporate management. That is a crucial consideration for the development of national innovation strategy as well as the entire innovation system.

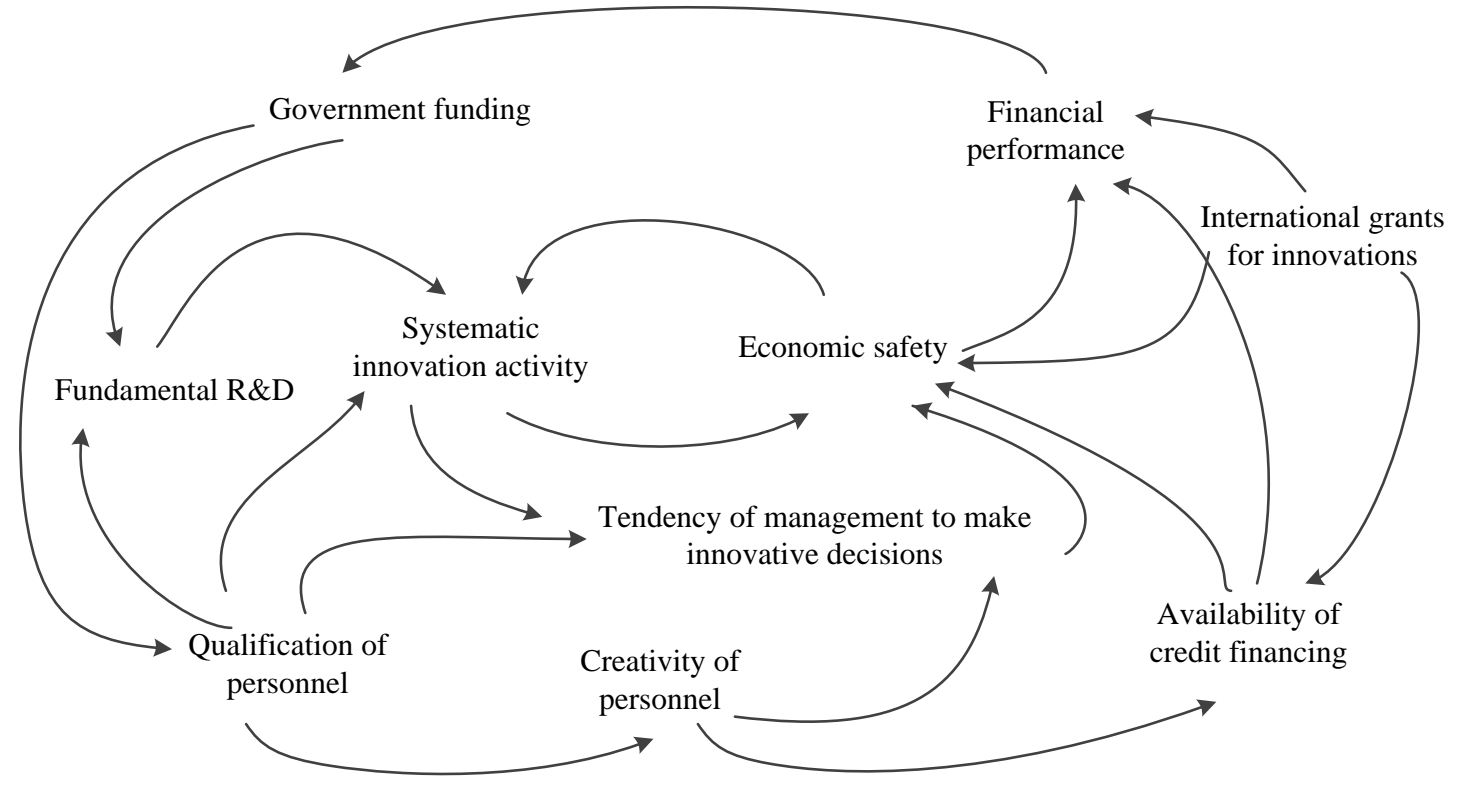

Fig. 4. Cognitive map for government maintenance of innovation activity

Note. Built by authors

To achieve the aim of the research, an analysis of the economic safety of 93 corporations that carry out innovation activities of varying intensity was conducted. The totality of the investigated enterprises was divided into three groups based on the data on the frequency of implementation of 
innovation projects. The first group included enterprises that did not carry out innovative activity at all; the second group included enterprises that implement innovative projects unsystematically, from time to time; the third group consisted of companies that carry out innovative activities systematically, have long-term and short-term plans for the implementation of innovation projects. The assessment of economic safety was carried out according to the previously proposed method (Labunska, Petrova \& Prokopishyna, 2017) enhanced by including cognitive indicators for actors of constructed cognitive map (Fig. 4).

Using this approach, it was found that $43.21 \%$ of the surveyed enterprises did not innovate (the number of the first group was 35 enterprises), about $22 \%$ of the surveyed companies rarely implemented innovative projects, and only $34.57 \%$ of the investigated enterprises (the number of the third group was 28 enterprises) conduct innovative activities systematically and consistently. However, the revealed structure of the investigated companies is not stored in the analysis of the sample by the areas of the location of enterprises, for example, only $9.09 \%$ of the investigated enterprises located in the Kharkiv region declared systematic innovation activity.

The structure of the investigated set of enterprises according to the selected levels of innovation activity and levels of economic safety is shown in Table 2.

Table 2. Distribution of companies by levels of innovation activity and economic safety.

\begin{tabular}{|c|c|c|c|c|}
\hline \multicolumn{2}{|c|}{} & \multicolumn{3}{|c|}{ Innovation activity level } \\
\cline { 3 - 5 } \multicolumn{2}{c|}{} & $\begin{array}{c}\text { Innovation projects are } \\
\text { not implemented }\end{array}$ & $\begin{array}{c}\text { Innovation activity is } \\
\text { unsystematic }\end{array}$ & $\begin{array}{c}\text { Innovation activity is } \\
\text { systematic }\end{array}$ \\
\hline \multirow{2}{*}{} & Very high & - & $9.52 \%$ & $90.48 \%$ \\
\cline { 2 - 5 } & High & - & $25.00 \%$ & $75.00 \%$ \\
\cline { 2 - 5 } & Middle & $50.00 \%$ & $50.00 \%$ & - \\
\cline { 2 - 5 } & Low & $68.42 \%$ & $15.79 \%$ & $15.79 \%$ \\
\cline { 2 - 5 } & Very low & $73.91 \%$ & $26.09 \%$ & - \\
\hline
\end{tabular}

The calculated values (Table 2) demonstrate that systemic innovation activities provide a high level of economic safety: $90.5 \%$ investigated enterprises, the level of economic safety of which is characterized as "very high", systematically carry out innovation activities, the remaining $9.52 \%$ of enterprises carry out innovative projects irregularly; three-quarters of the investigated enterprises with a high level of economic safety conduct systematic innovation activity, $25 \%$ of companies with high financial safety innovate unsystematically; and vice versa, almost three-quarters $(73.91 \%)$ of the investigated enterprises that do not innovate, and one quarter (26.09\%) of enterprises that carry out innovative activities irregularly have a deficient level of economic safety.

So, in order to ensure national security, the government policy should stimulate enterprises to intensify innovation activities and implement innovation projects systematically. Promotion of systematic innovation activity in strategic period will also eliminate restrictive (negative) factors and accelerate propulsive (positive) factors, that impact on processes idealisation, production, commercialisation and dissemination of innovations (figure 4).

Cognitive simulation of decision-making for innovation activity involves the development of a cognitive map that assists managers in poorly structured situations. Justification of managerial decision based on the constructed cognitive map (figure 4) will benefit from application of fuzzy logic methods on the one hand, and the isolation and structuring of the causal relationships of the highly predictable factors on the other hand.

Application of cognitive simulation for the development of government support of the national innovation system allow decision-making in different conditions:

- Simple managerial situations, characterised by obvious causal (mostly linear) relationships between the primary factors and the absolute predictability of events. In this 
domain, the cognitive principles of management manifest themselves in the ability to apply the professional skills of public administration in the standard scenario effectively.

- Complicated situations characterised by causative relationships of events that require careful analysis and participation of a team of public administration experts to find the right solution to the problem. In this domain, cognitive modelling involves the development of a cognitive map, taking into account the time lag of the concept's operation. The main cognitive instrument is canonical correlation analysis, which allows assessments of interrelations between the main contextual factors and at least indicate certain trends and synergies.

- Complex situations characterised by low predictability of response on public administration ventures. In this domain, causation becomes clear only in retrospect, while the managerial problem needs to be addressed in the current period.

- Chaotic situations characterised by lack of time to understand the problem. The overall managerial situation is described as a crisis and requires managers to develop activities to transfer it to other domains (except for the domain of uncertainty).

- Disorder situations that cannot be managed in principle, since external factors influence them. The main task of public administration in this domain is to change the tendencies into any other domain. The preferable cognitive instruments are similar to the domain of chaos.

In general, the major progressive changes in the government maintenance of innovation activity are expected improvements in the financing mechanism of the research \& development and convergence of innovative ideas. For this purpose, government support programs for innovation development should include measures aimed at:

- ensuring stable financing of the leading national scientific institutions by systematic research programs;

- allocating funds to scientific programs and projects within the framework of programmatic funding for science based on the principles of competition, ensuring transparency of the decision-making process and establishing public control over the use of funds;

- targeted allocation of state budget funds to provide innovative projects of national importance;

- creation of target state funds and venture funds of innovative development with the purpose of diversification of sources of financing of scientific and technical research projects;

- creation of favourable regulatory and legal conditions for the activities of charitable organisations and other non-profit institutions aimed at financial and informational support of innovation activity;

- establishment of public-private partnership in the field of financing scientific and technical research projects to accelerate the commercialisation of innovative projects funded by the state;

- implementation of new financial instruments to support the development of innovative sectors of the economy, in particular by facilitating the redistribution of investment flows through business;

- stimulating the development of leasing, lending and risk insurance of scientific and technical research projects and entrepreneurial innovations;

- modernisation of capital markets based on legislative and institutional support of investment companies, joint investment institutions and insurance companies for accumulation of aggregate national savings and their orientation towards the innovative development of the real economy sector; 
- promotion of stabilisation of capital markets and their development for the needs of society in the innovation modernisation of the country's production potential at the expense of institutes of direct state investment from special funds;

- application of favourable tax regimes for $R \& D$ organisations and innovation-intensive business;

- simplification of tax administration mechanisms for taxpayers carrying out innovative activities on a systematic basis;

- introduction of tax and customs privileges for research organisations, innovation-intensive companies and entrepreneurs in the sphere of technological infrastructure;

- creation and implementation of mechanisms of state and non-state financing of participation of scientists in the international scientific and innovation projects.

Reforming the financial mechanism supporting innovation development will create the prerequisites for scientific and technical support of the transformation of the national economy into high-tech and competitive, which will ensure the acceleration of GDP growth and public welfare. At the same time, the consequences of reforming the mechanism of government financial support depend heavily on the growth of domestic production, its orientation towards innovation and technological modernisation, the intensification of innovation activities, and the introduction by enterprises of mechanisms for the systematic implementation of innovation projects. Increase of the demand for the scientific and innovative products is determined by the solvency of domestic enterprises, while opportunities for attracting additional funds in international financial markets depend on the level of profitability of industrial innovations. All mentioned interrelations should be taken into account in the process of reforming state policy measures in the field of innovative development of the country.

\section{Conclusion}

1. Cognitive instruments are justifiably used to assess the state of national innovation systems and can be successfully applied to substantiate feasible mechanisms of public administration in the field of innovation activity.

2. National innovation system represents a complex of institutions and mechanisms that ensure conditions for the creation, storage, distribution and industrial application of scientific and technical knowledge in the country. The main elements of the national innovation system are the subsystems that provide: (i) the generation of new knowledge, education and training; (ii) production and marketing of innovative products, convergence of innovative ideas; (iii) administration of activity of different research organizations and innovation-intensive companies, including financial support for research and development. The current state of Ukraine's national innovation system is beyond the bounds of economic safety. The level of safety of a company as a primary element of the national financial system increases in the case of systematic innovation activity. Therefore, the implementation of national policies that stimulate enterprises to introduce innovations on a systematic basis is urgent for Ukraine.

3. The strategic aim of the national innovation policy should become the creation of supportive environment that ensures the transformation of scientific ideas and developments into market products of an international level; commercialization and convergence of the results of innovation activities of research institutes and commercial enterprises, and also contributes to the enhancing of the research potential of domestic scientific schools.

\section{Acknowledgement}

This research was funded by a grant "Formation of the scientific and technological platform for the harmonisation of the socio-economic interests of Ukraine in the world economic space". (No. 0116U004521) from the Ministry of education and science of Ukraine. 


\section{References}

1. Appan, R., Bolton, D. E., Madhavaram, S. Strategy, Decision Making, and Cognition: An Integrative Perspective. International Journal of Strategic Decision Sciences (IJSDS), 2017, 8(3), p. 78-98.

2. Beck, M., Junge, M., Kaiser, U. Public Funding and Corporate Innovation, IPA Discussion Papers, No. 11196. Bonn: Institute of Labor Economics (IPA), 2017

3. Brymer R. A., Hitt M. A., and Schijven M., Cognition and human capital: the dynamic interrelationship between knowledge and behavior," in A.Burton-Jones \& J.-C. Spender (ed.) The Oxford Handbook of Human Capital, Oxford: Oxford University Press, 2011. p. 28 - 50

4. Carrington, D. J., Combe, I. A., Mumford, M. D. Cognitive shifts within leader and follower teams: Where consensus develops in mental models during an organizational crisis. The Leadership Quarterly, 2018

5. Daniels, K., Johnson, G., De Chernatony, L. Differences in Managerial Cognitions of Competition. British Journal of Management, 1994, 5, p. 21-S29.

6. Dutta S., Lanvin B., Wunsch-Vincent S. The Global Innovation Index 2017: Innovation Feeding the World / S. Dutta, B. Lanvin, S. Wunsch-Vincent. - Geneva: WIPO, 2017. 464 p.

7. Dutta S., Lanvin B., Wunsch-Vincent S. The Global Innovation Index 2018: Energizing the World with Innovation / S. Dutta, B. Lanvin, S. Wunsch-Vincent. - Geneva: WIPO, 2018.429 p.

8. Forrer, J., Kee, J. E., Newcomer, K. E., Boyer, E. Public-private partnerships and the public accountability question. Public administration review, 2010, 70(3), p. 475-484.

9. Franke, T., Knyphausen-Aufsess, D. On dominant logic: review and synthesis. Journal of Business Economics, 2014, 84(1), p. 27-70.

10. Gavkalova, N. L., Kolupaieva, I. V. Decentralization of public administration in the process of building a democratic society. Public Policy and Administration, 2018,17(2), p. 216-225.

11. Herstad, S., Sandven, T., Ebersberger, B. Recruitment, knowledge integration and modes of innovation. Research Policy, 2015, 44(1), p. 138-153.

12. Hobday, M. Firm-level innovation models: perspectives on research in developed and developing countries. Technology Analysis \& Strategic Management, 2005, 17(2), 121-146.

13. Hodgkinson, G. P., Healey, M. P. Coming in from the cold: The psychological foundations of radical innovation revisited. Industrial Marketing Management, 2014, 43(8), 1306-1313

14. Hussain, S. T., Abbas, J., Lei, S., Jamal Haider, M., Akram, T. (). Transactional leadership and organizational creativity: Examining the mediating role of knowledge sharing behavior. Cogent Business \& Management, 2017, 4(1), p. 1-11.

15. Intramural R\&D expenditure by source of funds. Eurostat database, 2019

16. Kilduff, M., Angelmar, R., Mehra, A. Top management-team diversity and firm performance: Examining the role of cognitions. Organization science, 2000, 11(1), p. 21-34.

17. Khodakivsky, Ye.I., Yakobchuk, V.P., Litvinchuk, I.L. Intellectual Property: Economic and Legal Aspects. Kyiv: Center for Educational Literature, 2014.

18. Labunska, S., Petrova, M., Prokopishyna, O. Asset and cost management for innovation activity. Economic Annals-XXI, 2017, 165(5-6), p. 3-18.

19. Lockwood, M. Humans valuing nature: synthesising insights from philosophy, psychology and economics. Environmental Values, 1999, 8(3), p. 381-401.

20. Madhavaram, S., Badrinarayanan, V., Granot, E. Approaching global industrial marketing from a managerial cognition perspective: a theoretical framework. Journal of Business \& Industrial Marketing, 2011, 26(7), 532-541.

21. Martin-Alcazar, F., Romero-Fernandez, P. M., Sanchez-Gardey, G. Effects of diversity on group decision-making processes: The moderating role of human resource management. Group Decision and Negotiation, 2012, 21(5), 677-701.

22. Panagiotou, G. The impact of managerial cognitions on the structure-conduct-performance (SCP) paradigm: A strategic group perspective. Management decision, 2006, 44(3), p. 423-441. 
23. Pine, B. J., \& Gilmore, J. H. A leader's guide to innovation in the experience economy. Strategy \& Leadership, 2014, 42(1), p. 24-29.

24. Porac, J. F., Thomas, H., Baden Fuller, C. Competitive groups as cognitive communities: The case of Scottish knitwear manufacturers. Journal of Management studies, 1989, 26(4), p. 397416.

25. Rasmussen, E. S., Petersen, N. H. Platforms for Innovation and Internationalization. Technology Innovation Management Review, 2017, 7(5), p. 23-31.

26. Ukraine Statistic Innovation Outlook - Kyiv : Geneza, 2019. - 368 p.

27. Uotila, T. P. Elicting Managerial Cognitions-The Role of Cognition in Management Research. Journal of Economics, Business and Management, 2015, 3(2), p. 221-225.

28. Van Rossem, A., Heusinkveld, S., Buelens, M. The consumption of management ideas: A cognitive perspective. Management Decision, 2015, 53(10), p. 2356-2376

29. Yang, Y., Narayanan, V. K., Baburaj, Y., Swaminathan, S. Team mental model characteristics and performance in a simulation experiment. Management Research Review, 2016, 39(8), p. 899-924.

Nataliia Gavkalova, Svitlana Labunska, Andriy Pylypenko, Olena Prokopishyna

\section{Viešojo valdymo atskaitomybès pažintiniai instrumentai kuriant nacionalinę inovacijų sistemą}

Anotacija

Pagrindinis šio straipsnio tikslas yra tirti kognityvines priemones, kurios prisidètu kuriant teisingą sprendimų prièmimą šalies inovacijų politikoje. Teorinėje apžvalgoje yra aptariamos ES šalių narių ir Ukrainos inovacijų politikų gairès ir įgyvendinimo procesai bei priežastys galinčios paskatinti inovacijų plètrą. Empyrinis tyrimas buvo grịstas Ukrainos pavyzdžiu, čia buvo analizuojamaos Ukrainos įmonių financiniai ir žmogiškieji pajegumai seikiant inovacijų sklaidos ir taikymo. İmonių financinių ir statistinių rodiklių bei vadybos schemų analizė parodė, kad įmonės nuolat diegiančios inovatyvius procesus ir naudojančius inovatyvius produktus savo veikloje, pasiekia aukštesni inovacijos lygị, turi daugiau galimybių plèsti savo veiklą bei yra atsparesnès iškilus financinèms grèsmèms. Šios įmonès dažniau ir lengviau geba iššūkius paversti galimybėmis.

Analitinio kognityvinio žinių kūrimas tapo pagrindu scenarijumi grịsto modelio sukūrime ir pritaikyme viešojo sektoriaus inovacijų skatinimui. Kongnityvinio modelio taikymas pasirodè ypač veiksmingas sprendžiant nuolat kintančius financinius klausimus, kurie yra tokie būdingi šiuolaikinei ekonomikai. Šio modelio nauda buvo pastebèta nagrinejant didelès rizikos inovacijas bei nacionalinès reikšmés inovacijų iggyvendinimą.

Svitlana Labunska - PhD (ekonomika), Buhalterijos ir verslo konsultavimo katedros profesore Nacionaliniame Simon Kuznets Kharkiv ekonomikos universitete.

email: svetlana.lab@gmail.com

Nataliia Gavkalova - PhD (ekonomika), Viešojo valdymo ir regioninès ekonomikos katedros profesorè Nacionaliniame Simon Kuznets Kharkiv ekonomikos universitete.

email:ngavl@ukr.net

Andriy Pylypenko - $\mathrm{PhD}$ (ekonomika), Buhalterijos ir verslo konsultavimo katedros vedejas Nacionaliniame Simon Kuznets Kharkiv ekonomikos universitete.

email: aapil@ukr.net 
Olena Prokopishyna - Buhalterijos ir verslo konsultavimo katedros asoc. profesore Nacionaliniame Simon Kuznets Kharkiv ekonomikos universitete.

email: elena_prokopishin@ukr.net

Svitlana Labunska - Dr. of Sciences (Economics), Professor of the Department of Accounting and Business Consulting, Simon Kuznets Kharkiv National University of Economics.

email: svetlana.lab@gmail.com

Nataliia Gavkalova - Dr. of Sciences (Economics), Professor of the Department of Public Administration and Regional Economics, Simon Kuznets Kharkiv National University of Economics. email: ngavl@ukr.net

Andriy Pylypenko - Dr. of Sciences (Economics), Head of the Department of Accounting and Business Consulting, Simon Kuznets Kharkiv National University of Economics.

email: aapil@ukr.net

Olena Prokopishyna - Associated Professor of the Department of Accounting and Business Consulting, Simon Kuznets Kharkiv National University of Economics.

email: elena_prokopishin@ukr.net 